\title{
Evaluation of Likelihood of Co-Occurrence of Erwinia amylovora with Mature Fruit of Winter Pear
}

\author{
Todd N. Temple, Virginia O. Stockwell, P. Lawrence Pusey, and Kenneth B. Johnson
}

First, second, and fourth authors: Department of Botany \& Plant Pathology, Oregon State University, Corvallis, OR 97331-2902; and third author: U.S. Department of Agriculture-Agricultural Research Service, Tree Fruit Research Laboratory, Wenatchee, WA. Accepted for publication 30 April 2007.

\begin{abstract}
Temple, T. N., Stockwell, V. O., Pusey, P. L., and Johnson, K. B. 2007. Evaluation of likelihood of co-occurrence of Erwinia amylovora with mature fruit of winter pear. Phytopathology 97:1263-1273.

Phytosanitary concerns about fire blight prohibit export of U.S.-grown pears to some countries without this disease. To examine these concerns, we evaluated the potential for co-occurrence of Erwinia amylovora with mature, symptomless winter pear fruit by inoculation experiments and by survey of commercial orchards. Immature pear and apple fruit were inoculated in orchards with E. amylovora strain $153 \mathrm{~N}$ as resuspended lyophilized cells or as ooze from diseased tissues. Regardless of inoculum source, population size of Ea153N on fruit declined by an order of magnitude every 3 to 4 days during the first 2 weeks after inoculation; at 56 days after inoculation, Ea153N was not detected, except on 1 of 450 fruit with 4 colony forming units (CFU). After inoculation of flowers,

tomless pear fruit from diseased branches was evaluated by enrichment assay and nested polymerase chain reaction of internal fruit core tissues; these assays failed to detect the pathogen in healthy fruit from diseased trees. At harvest, E. amylovora could not be detected on 5,599 of 5,600 fruit of d'Anjou pear sampled from commercial orchards in major production areas of the Pacific Northwest; one fruit yielded $32 \mathrm{CFU}$ of the pathogen. Postharvest, mature pear fruit contaminated with Ea153N and subsequently wounded required a dose of $>10,000$ cells at the wound site to allow for persistence of the pathogen through a 7-week-cold storage. We conclude that epiphytic E. amylovora shows similar survival characteristics on both pear and apple fruit, this pathogen is not an endophyte within mature symptomless pear fruit, its presence is exceptionally rare on commercially produced fruit, and that epiphytic survival of E. amylovora through a postharvest chilling period is unlikely given the unrealistically high population size required for persistence.
\end{abstract} calyx-end survival of Ea153N on pear and apple fruit declined from high populations at petal fall to a few cells at harvest, with no detection of the pathogen after a 7-week cold storage. Migration of Ea153N into symp-
Additional keywords: exotic pest quarantine, phyllosphere microbiology, risk assessment.
Fire blight, caused by the bacterium Erwinia amylovora, is an economically important disease of pear (Pyrus communis L.) and apple (Malus pumila P. Mill.) in many parts of the world (6). The pathogen is native to North America, but in the last century was introduced to Europe, the Middle East, and New Zealand. Retrospective analysis of these introductions (6), as well as experimental evidence $(7,21,37,38)$, have implicated pathogen-infested nursery stock and/or scion wood as the likely pathways of introduction. For countries in which E. amylovora is not present, importation of plants and scions from countries with fire blight is prohibited by phytosanitary regulation $(1,41)$. In addition, some countries also prohibit importation of mature, symptomless pear and apple fruit, although fruit as a vehicle for long-range introduction of E. amylovora has never been documented.

In particular, the likelihood of apple fruit as a vehicle for dissemination of E. amylovora has been the subject of considerable research and risk assessment proceedings (12,16,29,30,35,36, $39,41-43)$. In a recent World Trade Organization dispute resolution proceeding (41), a panel of judges, after reviewing scientific literature and expert testimony, concluded that there is no evidence that mature, symptomless apple fruit can be infected or infested endophytically by E. amylovora, and that epiphytic infestations of this pathogen on apple fruit are rare and limited to those harvested on or very close to blighted trees. Moreover, even though epiphytic infestations are present occasionally, there is no

Corresponding author: johnsonk@ science.oregonstate.edu

doi:10.1094/PHYTO-97-10-1263

(C) 2007 The American Phytopathological Society evidence that fruit can serve as a pathway for the dissemination of the fire blight pathogen (41). Thus, as also concluded earlier in a risk assessment (29), the likelihood that the dissemination pathway can be completed by commercial trade of mature, symptomless apple fruit is considered negligible (41).

In contrast to apple, the consideration of pear fruit as a dissemination vehicle for $E$. amylovora has received little research effort $(8,24)$. On average, pear cultivars are more susceptible to fire blight than cultivars of apple (6), a difference that in countries with fire blight, limits commercial production of pear to drier climates. Furthermore, perhaps because of greater susceptibility, immature pear fruit ( 1 to 3 months old) are routinely used as the bioassay material of choice to verify the pathogenicity of E. amylovora, regardless of the host of origin $(1,5)$. In a moist chamber, immature pear fruit develop symptoms of fire blight after a few days, and ooze of the pathogen is visible after 5 to 7 days (5). Mature pear fruit, in contrast, show resistance to inoculation with E. amylovora $(10,44)$, and decay of fruit by this pathogen is not recognized as a postharvest problem by the pear industry. Nonetheless, by implication and anecdotal reporting, healthy pear fruit have been assumed to have a comparatively greater likelihood of harboring populations of E. amylovora than fruit of apple (41).

The purpose of this study was to address questions concerned with the likelihood of co-occurrence of E. amylovora with mature, symptomless fruit of winter pear. The study was conducted within the context of the commercial fruit production system in the Pacific Northwest region of the United States. The semi-arid pear production areas within the region produce $2.5 \times 10^{7} \mathrm{~kg}$ of fresh market winter pears annually, of which 20 to $25 \%$ is exported to markets outside of the country. The primary cultivars are 
'd'Anjou' (80\%) and 'Bosc' (20\%), both of which require a postharvest chilling period of 4 to 6 weeks for the fruit to ripen properly (9). We developed four questions for detailed examination: (i) does E. amylovora survive as an epiphyte on pear fruit surfaces?; (ii) are commercial fruit produced within the region contaminated with E. amylovora?; (iii) does E. amylovora have a potential to reside endophytically within fruit produced on diseased trees?; (iv) and does the pathogen have the ability to survive on winter pear fruit through the required postharvest chilling period? These data are discussed in relation to a risk assessment model developed for apple fruit from the same production area (29); most experiments reported in this study involved apple fruit as a comparative control.

\section{MATERIALS AND METHODS}

Bacterial strains. Strains of E. amylovora and of Pantoea agglomerans were used in field and laboratory experiments. E. amylovora strain Ea153, originally isolated from a fire blight canker on an apple tree in Milton-Freewater, OR, shows virulence and aggressiveness characteristics typical of North American strains of E. amylovora (19). Ea153N is a spontaneous, nalidixic acid-resistant $(100 \mu \mathrm{g} / \mathrm{ml})$ selection of Ea153 with characteristics similar to the parental strain; Ea153N has been used as a representative pathogen strain in numerous field studies $(19,27,28$, 32,33). Ea153 $\mathrm{HrpL}^{-}$is an avirulent $h r p L$ mutant of Ea153 obtained using marker-exchange mutagenesis methods with donor strains provided by S. Beer (Cornell University, Ithaca, NY) (40); Ea153 $\mathrm{HrpL}^{-}$is resistant to kanamycin $(100 \mu \mathrm{g} / \mathrm{ml})$. P. agglomerans strain PaC9-1S is a spontaneous streptomycin $(100 \mu \mathrm{g} / \mathrm{ml})$ and rifampicin $(100 \mu \mathrm{g} / \mathrm{ml})$ resistant selection of $\mathrm{PaC} 9-1$, with characteristics similar to the original strain (18); this strain is an excellent colonist of pear and apple flowers (20) and has been used to suppress floral infection by E. amylovora $(19,27,28,32)$. Unless otherwise noted, inoculum of these strains consisted of lyophilized cells prepared at a titre of $1 \times 10^{11}$ to $1 \times 10^{12}$ colony forming units (CFU)/g (19); these preparations were produced once and stored at $-50^{\circ} \mathrm{C}$ with subsamples withdrawn for use in experiments.

Recovery of bacteria from sampled fruit. In all field experiments, fruit were sampled individually into resealable plastic bags $(20 \times 20 \mathrm{~cm})(100 \mu \mathrm{m}$ thickness, Saket Co., Azusa, CA) and transported to the laboratory in insulated chests with ice. The resealable plastic bags also were the vessel in which the fruit were washed for bacterial isolation. Depending on the fruit size and time of season, 1 to $50 \mathrm{ml}$ of sterile, $10 \mathrm{mM}$ phosphate buffer $(\mathrm{pH}$ 7) was added to each bag, followed by hand massage of the fruit sample (10 s) and sonication in a bath-style sonicator (2 min, Branson 2000, Danbury, CT). A total of 20 to $250 \mu \mathrm{l}$ of the wash suspension and up to two serial 100-fold dilutions were spread onto the surface of Miller Schroth (MS) medium with sorbitol as the carbon source for isolation of E. amylovora (24) and on Pseudomonas agar F (PAF, Difco Laboratories, Detroit, MI) for recovery of $\mathrm{PaC} 9-1 \mathrm{~S}$; these media were amended with cycloheximide $(50 \mu \mathrm{g} / \mathrm{ml})$ and, if necessary, the antibiotic selective for each individual strain (antibiotics and rates given above). The detection limit for the dilution plating assay was 100 to 5,000 CFU per fruit, depending on wash buffer volume. For samples with expected populations near or lower than 100 CFU per fruit, the wash suspension was passed through a 250 -ml filter sterilization apparatus (Millipore, Billerica, MA) fitted with a $0.2-\mu \mathrm{m}$ glass fiber filter membrane (Supor-200, $45 \mathrm{~mm}$ diameter, Pall Life Sciences, Ann Arbor, MI) (30). Membranes with the wash filtrate were incubated on the surface of the MS or PAF medium. The detection limit of the filtration assay has been reported previously as $19 \mathrm{CFU}$ (30); this limit was reevaluated for purposes of this study. For both recovery methods, CFU characteristic to each species were counted after 3 to 7 days incubation at room tem- perature $\left(20\right.$ to $24^{\circ} \mathrm{C}$ ). Sixty percent of the 19,200 fruit washings performed in this study required both recovery methods.

Survival of $\boldsymbol{E}$. amylovora on fruit in orchards. During the summers of 2004 and 2005, epiphytic survival experiments were established in experimental pear (Pyrus communis cv. Bosc, 37 years old) and apple orchards (Malus pumila cv. Gala, 5 years old) located near Corvallis, OR, and in an experimental pear orchard (cv. d'Anjou, 31 years old) located near Medford, OR. Ea153 (2004 only) and Ea153N were inoculated as lyophilized cells resuspended in distilled water at $1 \times 10^{7} \mathrm{CFU}$ per ml; inoculum was sprayed onto fruit to runoff with a hand-held, adjustable trigger sprayer (0.5 liter capacity). In addition, fresh ooze containing $10^{8}$ to $10^{9} \mathrm{CFU}$ of Ea153N was applied directly onto the calyx end of developing fruit with a no. 4 camel hair paint brush modified such that only two hairs remained. For this purpose, ooze inoculum was produced in the laboratory by stab inoculating Ea153N into detached, 1- to 2-cm diameter, immature pear fruit (cv. Bartlett) followed by incubation at room temperature for 5 to 7 days in crisper boxes lined with moist paper. Each year, the experiment was initiated in early May when calyx ends are oriented upward, and repeated in July, when calyx ends are oriented down. Each experiment was arranged as a randomized block design with three, single-tree replicates per treatment. Fruit that received inoculum of E. amylovora (50 per tree) were tagged with plastic ribbons or paint markings on the stem. Five fruit from each tree were sampled at $1 \mathrm{~h}$, and $3,7,14,35$, and 56 days after inoculation.

To determine where bacteria were most likely to be detected on developing fruit, additional inoculations were performed with Ea153N during the July inoculations. Thirty fruit were sampled from trees at $2 \mathrm{~h}$ and 1,2 , and 3 days after inoculation. In the laboratory, the stem (including attached flesh), a $2 \times 2 \mathrm{~cm}$ peel of skin (tissue from neck, body, or base of fruit), and calyx of each fruit were excised with a flamed knife, weighed, and washed in phosphate buffer. The wash of each subsample was dilution plated and filter assayed on MS. Also, an estimate of the population size of indigenous bacteria was obtained by dilution plating the fruit washes onto PAF.

Bacterial survival on fruit calyxes. In 2005 and 2006, flowers in the d'Anjou (Medford) and Bosc pear and Gala apple (Corvallis) orchards were inoculated at full bloom with Ea153N, Ea153 $\mathrm{HrpL}^{-}$, and $\mathrm{PaC}$-1S. The nonpathogenic strains were applied to near runoff at a concentration of $1 \times 10^{7} \mathrm{CFU}$ per ml; the inoculum concentration of Ea153N was reduced to $1 \times 10^{5}$ CFU per $\mathrm{ml}$ to limit infection. Ea153N was co-sprayed with fluorescent, yellow-green, carboxylate microspheres $\left(1 \times 10^{7}\right.$ per $\mathrm{ml}, 1-\mu \mathrm{m}$-diameter Fluoresbrite YG, Polyscience Inc., Warrington, PA), which, when applied to open flowers, adhere and remain detectable on the calyx of developing fruit through summer (33). Inocula were applied to near runoff ( 2 to 3 liters per tree) with a backpack sprayer equipped with a hand wand. To further limit the incidence of infection on trees treated with Ea153N, the bacteriostatic antibiotic oxytetracycline (0.2 g/liter a.i., Mycoshield $17 \%$, NuFarm Americas Inc., Burr Ridge, IL) was over-sprayed once (2005) or twice (2006) at 3 to 6 days after inoculation (32); also, beginning in May, diseased blossom clusters were pruned from trees during weekly visual inspections. The experiment was arranged in a randomized block design with three (2005) or five (2006) single tree replicates of each bacterial strain.

Initial establishment of the bacterial strains was evaluated on eight flowers sampled from each replicate tree at 8 days after inoculation. These flowers were washed individually in $1 \mathrm{ml}$ of sterile phosphate buffer and dilution plated (19). Similarly, five immature fruit per replicate tree were sampled and assayed for bacterial recovery at 70 to 90 days after inoculation (late June to early July). At harvest (late August), 270 symptomless fruit were bulk harvested from each treatment and subdivided into three groups: no further treatment, a dump tank disinfestation treatment 
(described below), and dump tank plus a 6-week-storage treatment at $2^{\circ} \mathrm{C}$. For all postharvest samples, the calyx region of each fruit was excised with a flamed knife and then washed and filter assayed. After washing, sampled flowers and calyxes from mature fruit of the Ea153N treatment were stored at $2{ }^{\circ} \mathrm{C}$ until they could be examined with the aid of a microscope (Leica DMRB, 485-nm excitation filter, 520-nm emission filter, Hamburg, Germany) for the presence of the fluorescent microspheres.

Surveys for $E$. amylovora on fruit from commercial orchards. During 2003, 2004, and 2005, fruit from a total of 56 pear orchards of cv. d'Anjou located in the Rogue (OR), Hood River (OR), Yakima (WA), Wenatchee (WA), and Okanogan (WA) valleys of the Pacific Northwest were sampled within 1 week of commercial harvest. At the time of sampling, the orchards were visually inspected for symptoms of fire blight and categorized as apparently symptomless or with fire blight in the orchard or adjacent cultivar block. Four healthy fruit were sampled individually from each of 25 haphazardly selected trees within each orchard. Fruit were stored at $2^{\circ} \mathrm{C}$ until washed and filter assayed for bacterial detection (0 to 2 weeks) (30). Fruit maturity was monitored with a hand-held penetrometer (model FT327, Facchini, Alfonsine, Italy), which averaged $6 \mathrm{~kg}$ at the time of processing. Once every 50 processed fruit, resuspended Ea153N (10 to $50 \mathrm{CFU}$ per $\mathrm{ml}$ ) was filter assayed as a positive control.

The colony morphology of bacterial isolates on MS from some commercial fruit was similar to that expected for colonies of E. amylovora. When observed, these isolates were cultured on PAF, CCT (17), and CG (11) to compare colony morphology to E. amylovora. In addition, the ability of recovered isolates to grow on nutrient agar (Difco Laboratories) at $37^{\circ} \mathrm{C}$ was determined; E. amylovora does not grow at this temperature. Isolates were evaluated for ability to induce fire blight after stab inoculation into immature Bartlett pear (5) and to induce the hypersensitive response after infiltration $\left(\approx 10^{8} \mathrm{CFU}\right.$ per $\left.\mathrm{ml}\right)$ into tobacco leaves (40). Isolates were tested for oxidase, urease, and phenylalanine deaminase and catalase activity following standard methods (26). In addition, for a subset of 179 isolates with one or more test results similar to E. amylovora, a nested polymerase chain reaction (23) for the ubiquitous plasmid of E. amylovora, pEA29, and gas chromatography, fatty acid methylesterase (GCFAME) were used to characterize isolates (34). Finally, for three isolates, partial sequence of $16 \mathrm{~S}$ rDNA (3) was obtained and compared in GenBank or CLUSTAL to known bacterial species.

Assay for resident E. amylovora within mature fruit. In 2004 and 2005, the potential for E. amylovora to reside inside symptomless fruit was evaluated in experimental d'Anjou pear orchards located near Medford, OR, and Orondo, WA. At full bloom, flower clusters near terminal ends of two branches on each of five trees were misted with Ea153N prepared at $1 \times$ $10^{9} \mathrm{CFU}$ per $\mathrm{ml}$; five additional trees were misted with water to serve as controls. Inoculated branches were enclosed in fiberglass mesh screen bags to limit insect visitation; these bags remained through the summer. At harvest, locations of 20 symptomless fruit were mapped on each tree and sampled individually. The fruit were filter assayed immediately for the external incidence of E. amylovora and then placed into cold storage $\left(2^{\circ} \mathrm{C}\right)$ for 6 weeks.

After storage, the fruit were surface disinfested in $0.6 \% \mathrm{NaOCl}$ for $5 \mathrm{~min}$ followed by removal of the stem and calyx regions with a flamed knife. Cut fruit were surface disinfested a second time for $1 \mathrm{~min}$ in $0.6 \% \mathrm{NaOCl}$, rinsed with distilled water, and then cored with a flamed no. 9 cork borer. Cores were placed individually into resealable plastic bags with $5 \mathrm{ml}$ of sterile $10 \mathrm{mM}$ phosphate buffer $(\mathrm{pH} \mathrm{7)}$ and gently macerated with a rubber-coated hammer. Two 1-ml subsamples of each macerated core were frozen at $-80^{\circ} \mathrm{C}$ in $10 \%$ ( $\mathrm{vol} / \mathrm{vol}$ ) glycerol. Nutrient yeast extract broth $(30 \mathrm{ml})$ was added to the remaining macerate solution. Macerate and broth were incubated at room temperature for $30 \mathrm{~h}$ on a rotary shaker at $200 \mathrm{rpm}$. After incubation, three $0.25-\mathrm{ml}$ samples of each core macerate were spread on MS medium.

Macerated core subsamples were subjected to DNA extraction and a nested PCR for detection of pEA29 of E. amylovora (23). Five microliters of core tissue was mixed with $5 \mu \mathrm{l}$ of GeneReleaser (BioVentures, Inc., Murfreesboro, TN) in 0.2-ml PCR strip tubes. After the first PCR, a 1- $\mu$ l subsample of the reaction mixture was used as template for the second PCR. PCR products were visualized after electrophoresis on $1.5 \%$ agarose gel. Purified pEA29 $(50 \mathrm{ng} / \mu \mathrm{l})$ (4) and macerated pear mixed with Ea153N to a final concentration of $1 \times 10^{1} \mathrm{CFU} / \mathrm{ml}$ were used as positive controls.

Survival of $\boldsymbol{E}$. amylovora on stored fruit. A suspension of fresh Ea153N cells scraped from agar cultures was prepared at $5 \times 10^{7} \mathrm{CFU} / \mathrm{ml}$ and sprayed with a hand pump sprayer to runoff onto 240 fruit. Fruit were allowed to air dry for $2 \mathrm{~h}$. Inoculated fruit were divided into three treatments: ambient, defined as storage on cardboard trays in a box bagged with plastic and placed inside an incubator set at $20^{\circ} \mathrm{C}$; refrigerated regular atmosphere $\left(21 \% \mathrm{O}_{2}, 0.1 \% \mathrm{CO}_{2}\right)$; or refrigerated controlled atmosphere $(1.5 \%$ $\mathrm{O}_{2}, 1 \% \mathrm{CO}_{2}$ ). Refrigerated chambers were set at $0^{\circ} \mathrm{C}$ with a relative humidity of 86 to $90 \%$. Fruit that received refrigerated treatments were divided among 14 fabricated chambers (each $0.14 \mathrm{~m}^{3}$ ) with atmospheres established and maintained by a computerized monitoring system (Technical Consulting Services, Chelan, WA). Use of multiple chambers allowed for samples to be taken over time without disturbing the atmospheres around fruit stored for longer periods. Population sizes of Ea $153 \mathrm{~N}$ on 10 fruit per treatment were determined by dilution plating and filter assay at 0,1 , $3,5,7,14,28$, and 56 days inoculation. The experiment was performed twice.

In 2004, 2005, and 2006, 300 healthy, mature pear fruit (cv. d'Anjou) from Medford, OR, and from Wenatchee, WA (2005 and 2006 only), and 300 apple fruit (cv. Braeburn) from Corvallis, OR, and from Wenatchee, WA (cv. Gala 2005, cv. Braeburn 2006), were bulk harvested and transported to the laboratory. In the lab, fruit were surface disinfested in $0.6 \% \mathrm{NaOCl}$, rinsed in sterile water, and air dried. After drying, a 10- $\mu$ l drop that contained resuspended, lyophilized cells of Ea153N was placed onto a marked position on the side of each fruit. Inoculum concentrations were $0,10,100$, and 1,000 cells per drop in 2004, and 0, 1,000, and 10,000 cells per drop in 2005 and 2006. Each dose was applied to three replications of 30 fruit (90 fruit per inoculum dose per cultivar). Once the drop of inoculum was air dry, a 1- $\times 3-\mathrm{mm}$-deep skin puncture was introduced at the site of inoculation with a sterile, 4D steel finishing nail secured through a wood block. After wounding, fruit were incubated at room temperature for $24 \mathrm{~h}$ followed by a dump tank immersion in $1.5 \%$ sodium ortho-phenylphenate (SOPP, Columbia Technical Assoc., Wenatchee, WA) for pear (and apple in 2006) or $0.006 \% \mathrm{NaOCl}$ (100 ppm of chlorine) for apple (and pear in 2006) and then placed in a 0 to $3^{\circ} \mathrm{C}$ cold room for up to 49 days. SOPP and $\mathrm{NaOCl}$ are standard disinfectants used in commercial flotation systems for pear and apple, respectively. Fruit were assayed for Ea153N on day 0 (pre- and post-dump tank), 7, 14, 28, and 49. In 2005 and 2006, additional inoculated fruit were removed from cold storage after 49 days and incubated at room temperature for up to an additional 30 days. At each sampling time, tissue immediately surrounding the wound site $(1 \mathrm{~cm}$ diameter $\times 5 \mathrm{~mm}$ in depth) was cut from 15 fruit per inoculum dose. Tissue samples were macerated with a sterile glass rod in $4 \mathrm{ml}$ of sterile phosphate buffer, filter assayed, and incubated on MS medium.

Weather data. Orchard weather conditions were obtained from automated weather stations located within experimental orchards near Corvallis and Medford, OR, and Wenatchee, WA. These data are available online (AGRIMET and METAR weather networks, Integrated Plant Protection Center, Oregon State University). 
Data summary. For all experiments, the incidence of recovery of the inoculated bacterial strains was determined for each replicate of sampled fruit (or flowers) on each sample date. Replicate means for population size of a strain were determined similarly, but only for fruit (or flowers) on which a strain was detected (33). In the computation of means, a $\log _{10}$ transformation of bacterial population size on an individual fruit was performed prior to averaging; also, in those cases where counts of recovered CFU were considered very low $\left(\leq 10^{3} \mathrm{CFU}\right)$, means of untransformed counts of CFU were determined. Survival of E. amylovora and $P$. agglomerans as epiphytes on fruit and fruit calyxes, as measured by incidence of recovery and mean population size, were plotted in temporal arrays as a function of days after inoculation.

Analysis of variance (ANOVA) was performed on several data sets. Inoculum type and host cultivar were compared in the epiphytic survival experiments with two-factor ANOVA models. Similarly, the effects of bacterial strain and host cultivar were determined in the calyx-end survival experiments. Effect of storage atmosphere was evaluated in the postharvest experiments; and effect of inoculum dose and cultivar was compared in the postharvest wounding experiment. Relative area under the incidence of recovery curve $\left(A_{\text {inc }}\right)$ was the principle variable evaluated by ANOVA. This variable (in essence, a weighted average of recovery of a bacterial strain over the observed time period) was calculated as

$$
A_{\text {inc }}=\left[\sum_{i=2}^{n}\left(y_{i}+y_{i-1}\right) / 2 \times\left(t_{i}-t_{i-1}\right)\right] /\left(t_{n}-t_{1}\right)
$$

where $y$ and $t$ are the incidence of recovery of a bacterial strain and day from inoculation, respectively, for the $i$ th sample date, and $n$ is the total number of sample dates during the bloom period. Treatment effects were evaluated by the $F$ test, and means were separated using Fisher's protected least significant difference at $P=0.01$

\section{RESULTS}

Evaluation of bacterial recovery methods. With the dilution plating method, the lower limit for reliable detection of bacterial CFU occurred in the range of $1 \times 10^{2}$ to $1 \times 10^{3} \mathrm{CFU}$ per fruit or per $\mathrm{ml}$ depending on the volume of the wash buffer; below this range, the filter assay method provided superior results (Table 1). Within their respective range, dilution plating of cells dried onto and washed from fruit surfaces had a ratio of recovered cells to estimated inoculum density that averaged $55 \%$, but this ratio dropped to $5 \%$ for the filter assay method (Table 1). In contrast, for cells resuspended into fruit macerate, the ratio of recovered cells to estimated inoculum density averaged 83 and $71 \%$ for the dilution plating and filter assay methods, respectively. At the lowest inoculum density applied to fruit surfaces, the ratio of recovered cells to estimated inoculum density was $5 \%$ for $43 \mathrm{CFU}$ of E. amylovora inoculated onto a pear fruit surface and then allowed to dry. This sensitivity and efficiency of recovery is similar to a previously reported detection limit for the filter assay method (30).

Survival of $\boldsymbol{E}$. amylovora on fruit in orchards. On the day of inoculation, E. amylovora strains Ea153N and Ea153 were recovered from $100 \%$ of fruit from all cultivars in all experiments $(n=450)$ (Fig. 1A to C). Average initial population sizes were $4.3 \times 10^{5} \mathrm{CFU}$ for resuspended cells sprayed onto fruit surfaces, and $1.6 \times 10^{7} \mathrm{CFU}$ per fruit for cells produced in ooze and brushed onto fruit calyxes (Fig. 1D to F). By 7 days after inoculation, measurable populations of the pathogen on fruit had decreased by two to three log units (90 to $99 \%$ ) regardless of cultivar or strain treatment. Incidence of recovery also declined rapidly after inoculation, with the pathogen being detected on approximately $40 \%$ of the fruit at 7 days after inoculation, declining to $<5 \%$ fruit at 5 weeks after inoculation. At 56 days after inoculation, E. amylovora was not detected on any fruit of d'Anjou pear or Gala apple ( $n=150$ fruit per cultivar); however, one ooze-inoculated fruit of Bosc pear yielded 4 CFU (May 2004 inoculation). At no time were symptoms of fire blight apparent on any of the 90 trees that received pathogen inoculum; the pathogen was not detected on control fruit treated with water.

Extinction curves for E. amylovora on fruit as a function of time showed similar shapes among cultivar and inoculum treatment, but with consistently higher incidence of recovery of the pathogen obtained for cells applied in ooze compared with cells resuspended in water, and for cells recovered from rougherskinned Bosc pear as opposed to smooth-skinned d'Anjou pear or Gala apple (Fig. 1). ANOVA of relative area under incidence of recovery curve confirmed these observations with $A_{\text {inc }}$ values for cells in ooze being significantly greater than resuspended cells in all experiments $(P$ values ranged from $<0.0001$ to 0.0045$)$, and $A_{\text {inc }}$ for Bosc pear being significantly greater than the other cultivars in both of the 2004 experiments $(P<0.0001)$. In 2004, $A_{\text {inc }}$ for Ea153 and Ea153N resulted in similar values $(0.148 \pm$ 0.033 [standard error] and $0.156 \pm 0.042$, respectively), and consequently, the wild-type strain, Ea153, was not included in the 2005 experiment. Within a season, the differences in $A_{\text {inc }}$ values for the same treatment between the early and late summer experiments were small $(<10 \%)$, but $A_{\text {inc }}$ values measured in 2004 were twice those measured in 2005.

Isolation from specific areas of selected pear fruit $(n=570)$ influenced recovery of the pathogen. After the day zero sample, Ea153N was not recovered from peel tissue or stem tissue, but other bacteria continued to be recovered from stem tissues (but not peel) at population sizes between $1 \times 10^{2}$ and $1 \times 10^{3} \mathrm{CFU} / \mathrm{g}$. For calyx ends of pear fruit, Ea153N was detected on all sample dates (i.e., 0, 1, and 3 days after inoculation) at incidences ranging from 60 (day 0 ) to $10 \%$ (day 3 ), and at populations up to $1 \times$ $10^{5} \mathrm{CFU} / \mathrm{g}$ on day 0 and $1 \times 10^{3} \mathrm{CFU} / \mathrm{g}$ on day 3 (data not shown).

TABLE 1. Recovery of Erwinia amylovora strain Ea153N from inoculated pear fruit surfaces and macerates

\begin{tabular}{|c|c|c|c|c|c|c|}
\hline \multirow[b]{2}{*}{ Recovery method } & \multicolumn{3}{|c|}{ Fruit surface ${ }^{a}$} & \multicolumn{3}{|c|}{ Fruit macerate ${ }^{b}$} \\
\hline & $\begin{array}{l}\text { Inoculum dose } \\
\left.\text { (CFU fruit }^{-1}\right)\end{array}$ & $\begin{array}{l}\text { Recovered } \\
\left(\mathrm{CFU} \mathrm{fruit}^{-1}\right)\end{array}$ & $\begin{array}{l}\text { Ratio of } \\
\text { recovery }\end{array}$ & $\begin{array}{l}\text { Inoculum dose } \\
\quad\left(\mathrm{CFU} \mathrm{m} \mathrm{m}^{-1}\right)\end{array}$ & $\begin{array}{l}\text { Recovered } \\
\left(\mathrm{CFU} \mathrm{m} \mathrm{m}^{-1}\right)\end{array}$ & $\begin{array}{l}\text { Ratio of } \\
\text { recovery }\end{array}$ \\
\hline Dilution plate & $13,000 \pm 1,100^{\mathrm{c}}$ & $5,700 \pm 6,000$ & 0.44 & $16,000 \pm 8,800$ & $14,000 \pm 5,200$ & 0.87 \\
\hline Dilution plate & $500 \pm 210$ & $330 \pm 100$ & 0.66 & $620 \pm 96$ & $490 \pm 71$ & 0.79 \\
\hline Filter assay & $500 \pm 210$ & $25 \pm 29$ & 0.05 & - & - & - \\
\hline Filter assay & $43 \pm 27$ & $2 \pm 2$ & 0.05 & $58 \pm 7$ & $41 \pm 20$ & 0.71 \\
\hline
\end{tabular}

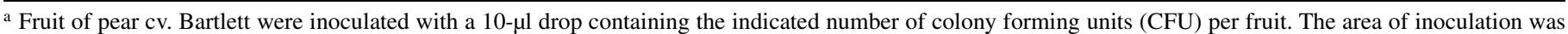
estimated to be $0.1 \%$ of the fruit surface. Inoculum consisted of resuspended freeze-dried Ea153N, which was allowed to dry for 2 h after placement on the fruit. Fruit were washed in $30 \mathrm{ml}$ of phosphate buffer (10 mM, pH 7.0), sonicated for $2 \mathrm{~min}$, followed by dilution plating and/or filter assay onto Miller Schroth medium.

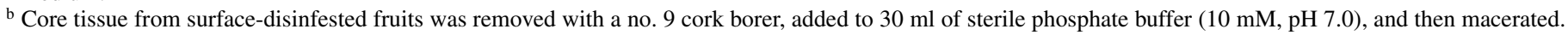
Resuspended freeze-dried Ea153N was added to the macerate to obtain the indicated number of CFU per milliliter. Resulting macerate was dilution plated and/or filter assayed onto Miller Schroth medium.

${ }^{c}$ Each mean (and standard deviation) was computed from eight replicates. Data represent combined results of two independent experiments. 
Bacterial survival on fruit calyxes. For orchard experiments conducted in 2005 and 2006, pear flowers sprayed with Ea153N, Ea153 $\mathrm{HrpL}^{-}$, and $\mathrm{PaC} 9-1 \mathrm{~S}$ yielded incidences of recovery at 8 days after inoculation that averaged 72, 95, and 89\%, respectively (Fig. $2 \mathrm{~A}$ and B). Similarly, incidences of recovery of Ea153N, Ea153 $\mathrm{HrpL}^{-}$, and PaC9-1S from sampled flowers of Gala apple were 47, 92, and 93\%, respectively (Fig. 2C). Initial population sizes of the inoculated strains on flowers from which the respective bacteria were detected ranged from $1.0 \times 10^{2}$ to $1.8 \times 10^{5}$ CFU per flower, with generally similar means obtained among the strains and cultivars (Fig. 2D to F). For flowers treated with virulent Ea153N, the development of fire blight on inoculated clusters in 2005 occurred at relatively low incidence in d'Anjou pear $(<10 \%)$ but at high incidence in Bosc pear and Gala apple $(>60 \%)$; in contrast, in 2006, incidences of diseased blossom clusters were high for d'Anjou and Bosc pear (> 80\%) and low for Gala apple $(<20 \%)$. Diseased blossom clusters were removed as detected.

Temporal patterns of strain survival in association with calyx ends of healthy, developing fruit were similar among the 2005 and 2006 seasons (Fig. 2A to F). The nonpathogenic epiphyte, $P$. agglomerans strain $\mathrm{C} 9-1 \mathrm{~S}$, persisted through to harvest $(\approx 150$ days after inoculation) in populations averaging $>1 \times 10^{4} \mathrm{CFU}$ per calyx on most inoculated pear and apple fruit. Conversely, incidence and population size of virulent Ea153N and avirulent Ea153 $\mathrm{HrpL}^{-}$declined progressively through the summer. In 2005, neither strain of E. amylovora could be detected on symptomless fruit sampled at harvest, whereas in 2006, these strains persisted on $7 \%$ of pear fruit but could not be detected on apple (Fig. 2); when recovered on pear, the population size averaged $7 \mathrm{CFU}$ per fruit. In contrast to E. amylovora, fluorescent microspheres applied with the inoculum were detected on 80 to $100 \%$ of flowers and fruit sampled at midsummer. For the harvest, postdump tank and post-cold storage sampling times, the incidence of microspheres on calyxes averaged 76, 81, and $73 \%$ for d'Anjou pear; 72,82 , and $79 \%$ for Bosc pear; and 85,94 , and $88 \%$ for Gala apple, respectively $(n=90$ for each fruit type on each sample date).

For all experiments, $A_{\text {inc }}$ values for $P$. agglomerans strain PaC9$1 \mathrm{~S}$ were significantly greater $(P<0.0001)$ than corresponding values for Ea153N and Ea153 $\mathrm{HrpL}^{-}$. After a 7-week cold storage period, an enrichment assay involving calyx ends of fruit placed in MS broth yielded growth of PaC9-1S from $100 \%$ of samples $(n=13)$, but this assay failed to detect Ea153N or Ea153 $\mathrm{HrpL}^{-}$on fruit $(n=60)$ from trees inoculated with these strains. Control samples $(n=9)$ spiked with 5 to $10 \mathrm{CFU}$ of PaC9-1S, Ea153N, and $\mathrm{Ea} 153 \mathrm{HrpL}^{-}$all yielded a positive detection (data not shown).

Surveys for $E$. amylovora on fruit from commercial orchards. Of the 56 surveyed orchards, at the time of harvest, 15 (27\%) had fire blight symptoms present in the orchard or in an adjacent block of a different cultivar; whereas the remaining 41 orchards $(73 \%)$ were apparently disease free as determined by visual inspection. At least some bacteria were recovered on filter membranes of nearly all fruit washings, many of which were green-colored on MS medium and fluoresced when transferred to PAF medium, indicative of Pseudomonas spp. Orange to red colonies with resemblance to E. amylovora on MS medium were recovered from $15 \%$ of washed fruit; a subset of 179 orange/red colonies were selected and tested for identification (Table 2). Partial identification of the orange/red-colored isolates by fatty
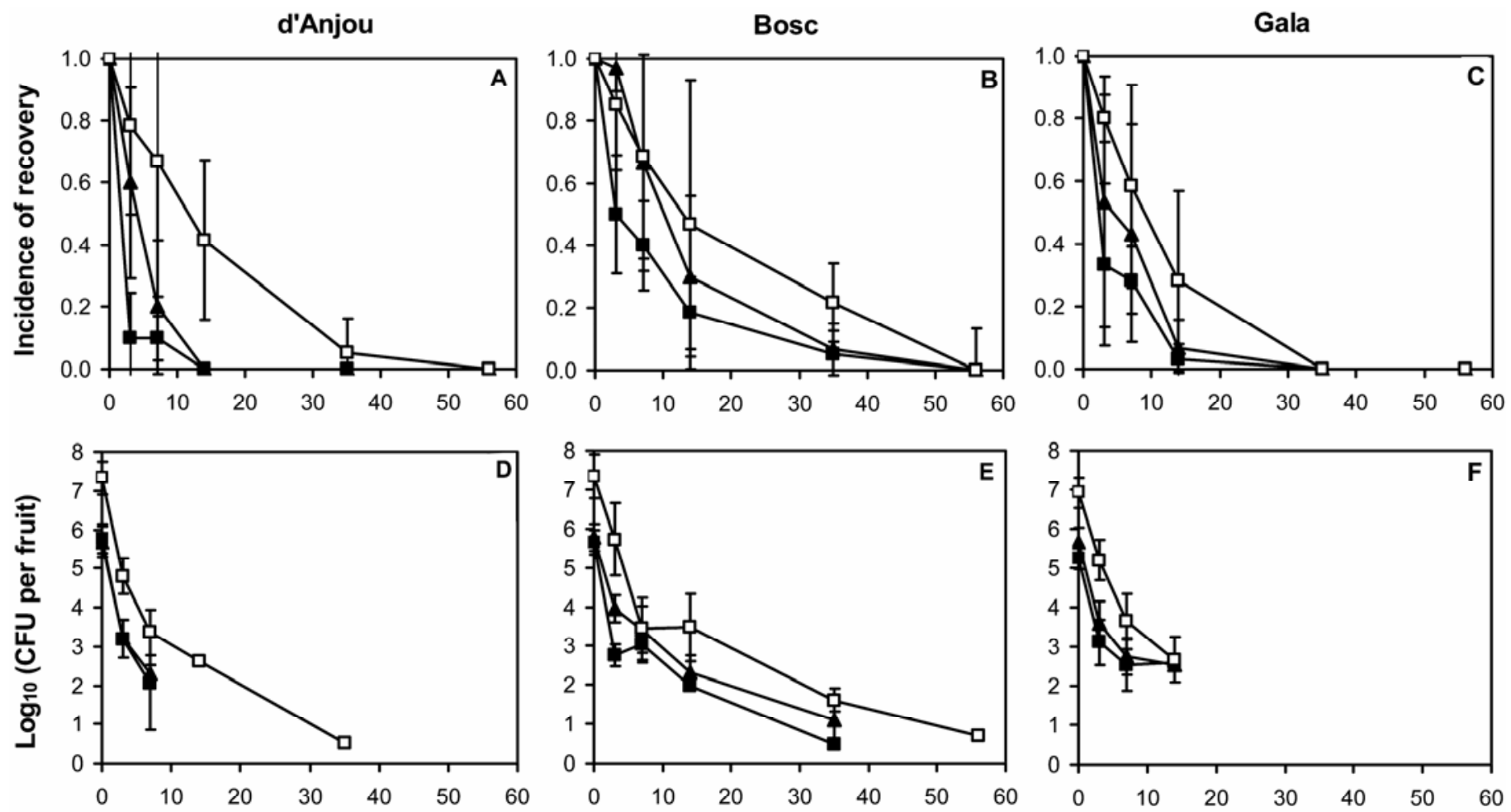

Days after fruit inoculation

Fig. 1. A to C, Incidence of recovery and $\mathbf{D}$ to $\mathbf{F}$, mean size of detectable populations (expressed as $\log _{10}[\mathrm{CFU}$ per fruit]) of Erwinia amylovora strains Ea153N and Ea153 on surfaces of pear and apple fruit after inoculation in orchards located near Medford ('d'Anjou' pear) and Corvallis, OR ('Bosc' pear and 'Gala' apple) during the summers of 2004 and 2005. Each panel depicts a summary of four experiments initiated in mid-May and early-July of both seasons. Inoculum was applied to fruit as resuspended freeze-dried cells prepared at $1 \times 10^{7} \mathrm{CFU} / \mathrm{ml}$ and sprayed to runoff ( Ea153N, $\boldsymbol{\Delta}$ Ea153; strain Ea153 was applied in 2004 only), or cells in ooze $(\square \mathrm{Ea} 153 \mathrm{~N})$ produced on diseased immature fruit of 'Bartlett' pear and applied with a small brush directly onto the calyx area of each fruit; the ooze applied to each fruit contained $10^{8}$ to $10^{9} \mathrm{CFU}$ of Ea153N. For each sample time, five fruit were sampled from each of three replicate trees per experiment, washed individually, and dilution plated and/or filter assayed onto Miller Schroth medium. Vertical bars drawn through each point represent \pm one standard deviation of the mean. 
acid analysis (GC-FAME) most frequently yielded Enterobacter (8\%), Pantoea (12\%), and Pseudomonas spp. (8\%), and a few nonpathogenic Erwinia spp. (2\%) (E. rhapontici and E. persicina).

A total of 3 of 179 orange/red isolates produced a hypersensitive reaction (HR) in tobacco leaves, indicative of a type III secretion system. Partial sequences of the $16 \mathrm{~S}$ rDNA of these isolates yielded (with $>99 \%$ similarity in GenBank) E. amylovora, E. persicina, and Citrobacter freundii. The one isolate identified as E. amylovora by its $16 \mathrm{~S}$ rDNA sequence also was positive for production of ooze on immature pear and for presence of pEA29; all other isolates were negative for these tests (Table 2). Consequently, $1(0.02 \%)$ of 5,600 pear fruits sampled from commercial orchards yielded $32 \mathrm{CFU}$ of E. amylovora (Table 3 ).

Assay for resident $\boldsymbol{E}$. amylovora within mature fruit. In both seasons, the controlled inoculation of specific branches of d'Anjou pear with Ea153N resulted in two diseased branches on each of the experimental trees at each location $(n=20$ diseased trees). These cankers expanded through the spring and summer, and measured 0.5 to $1.0 \mathrm{~m}$ at harvest. In September, 20 mature symptomless fruit on each replicate tree were mapped for proximity to a canker and harvested. Over both locations and years, external washings of fruit $(n=400)$ resulted in one isolation $(0.25 \%)$ of $33 \mathrm{CFU}$ of Ea153N (Wenatchee experiment, 2005); this fruit was located $5 \mathrm{~cm}$ from the proximal edge of canker. Positive isolation of Ea153N was confirmed by resistance to nalidixic acid at $100 \mu \mathrm{g} / \mathrm{ml}$, and by assay for pEA29, tobacco HR, and ooze production in immature pear.

Ea153N was not detected in core tissues of sampled fruit $(n=$ 400) in any experiment determined by either enrichment assay or nested PCR amplification of pEA29. Similarly, fruit $(n=250)$ from nondiseased trees failed to yield Ea153N. All control samples $(n=30)$ spiked with $1 \times 10^{1}$ to $1 \times 10^{5} \mathrm{CFU}$ of Ea153N resulted in positive detection of the pathogen with both assay methods.

Postharvest survival of $\boldsymbol{E}$. amylovora on stored fruit. As in the orchard experiments, Ea153N was recovered from $100 \%$ of inoculated mature fruit sampled and assayed prior to assignment to one of three postharvest storage treatments (Fig. 3A); initial population sizes on the fruit averaged $1.3 \times 10^{6} \mathrm{CFU}$ per fruit (Fig. 3B). Incidence of recovery of Ea153N over time was influenced strongly by storage condition, with the ambient treatment $\left(20^{\circ} \mathrm{C}\right)$ showing a rapid decline in proportion of fruit with detectable pathogen populations (from 100 to $22 \%$ ) over the first 14 days of storage; in contrast, the refrigerated controlled atmosphere $\left(0^{\circ} \mathrm{C}, 1.5 \% \mathrm{O}_{2}, 1 \% \mathrm{CO}_{2}\right)$ treatment showed only a slight decline in the recovery incidence (from 100 to $96 \%$ ) over the first 28 days of storage (Fig. 3), but an accelerated decline over the latter half of the storage period (Fig. 3A). For both experiments, ANOVA of $A_{\text {inc }}$ values confirmed a significant effect of storage environment $(P<0.0001)$. Population sizes of Ea153N on stored fruit declined steadily over time with the rate of decline also affected by storage environment (Fig. 3B). These declines in population size averaged a $\log$ unit for every 2,5 , and 7 days of storage in the ambient, regular, and controlled atmosphere treatments, respectively (Fig. 3B). For all treatments, mean populations declined to $<1 \times 10^{4} \mathrm{CFU}$ per fruit by 14 days of storage, and for the refrigerated treatments, the pathogen was undetectable on fruit $(n=40)$ stored for 56 days (for the ambient treatment, continuous ripening of fruit prevented sampling beyond 28 days).

Pathogen survival near wounds on stored fruit. The detection of Ea153N near small skin punctures on mature fruit was dependent on the inoculum dose. Of the doses evaluated in 2004 (water control, and $1 \times 10^{1}, 1 \times 10^{2}$, and $1 \times 10^{3} \mathrm{CFU}$ per wound site), only the highest dose resulted in pathogen recovery from the wound site after the dump tank treatment (Table 4). At
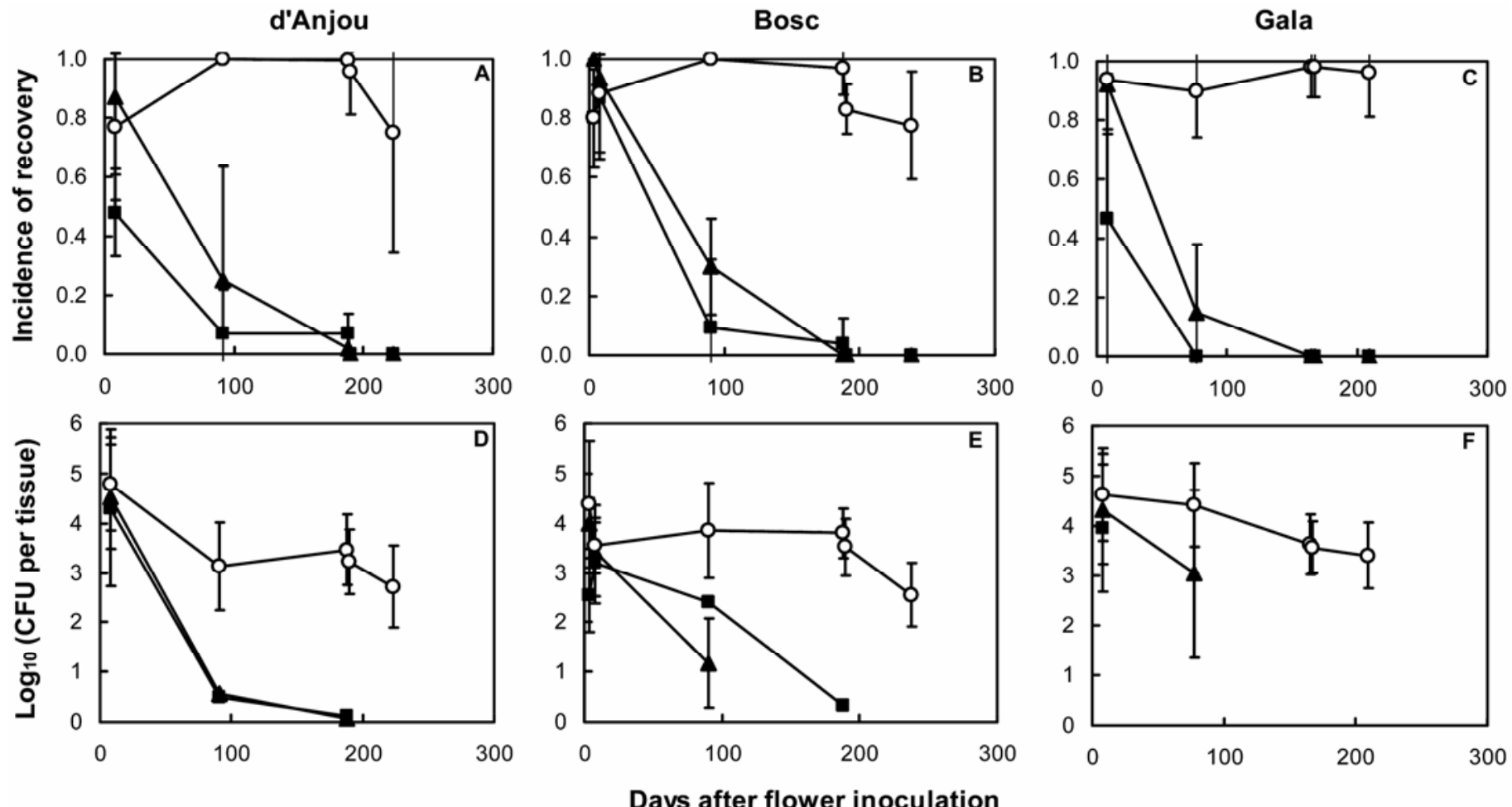

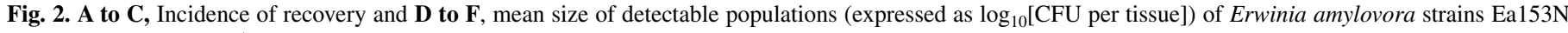

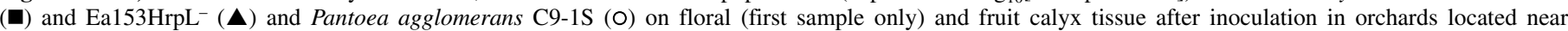

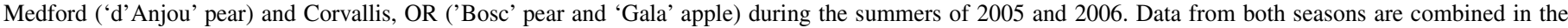

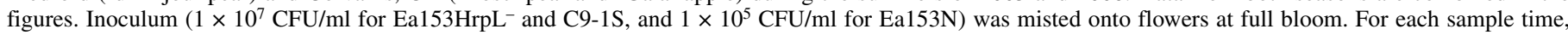

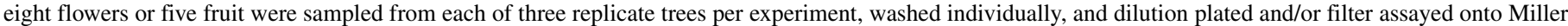

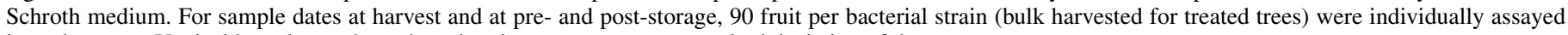
in each season. Vertical bars drawn through each point represent \pm one standard deviation of the mean. 
this dose, Ea153N was detected on $27 \%$ of d'Anjou pear after 7 and 14 days of cold storage ( 0 to $2{ }^{\circ} \mathrm{C}$, regular atmosphere) and on $20 \%$ of Braeburn apple after 7 days storage; the pathogen was not detected on any fruit $(n=480)$ stored longer than 14 days. When detected, the mean recovered population size of Ea153N was $<1 \times$ $10^{2} \mathrm{CFU}$ per fruit (Table 4). A dose of $1 \times 10^{3} \mathrm{CFU}$ per wound site yielded similar results in the 2005 and 2006 experiments with no detection of the pathogen beyond 7 or 14 days from apple and pear, respectively.

The dose of $1 \times 10^{4} \mathrm{CFU}$ per wound site, evaluated in 2005 and 2006 experiments, increased persistence of the pathogen on fruit relative to a dose of $1 \times 10^{3} \mathrm{CFU}$ per wound site, which was evaluated in all years of the study (Table 4). For pear, at the highest dose, populations of the pathogen between $1 \times 10^{2}$ and $1 \times 10^{3}$ CFU per wound site were detected on 13 to $37 \%$ of fruit at 49 days after inoculation; on apple, smaller populations (between $1 \times 10^{1}$ and $1 \times 10^{2} \mathrm{CFU}$ per wound site) were detected on 13 to $20 \%$ of apple fruit at 28 days after inoculation. For both fruit types, the incidence of detection of Ea153N was highest at the pre-dump tank assessment (except for pear in 2006 with $\mathrm{NaOCl}$ as the disinfestant) followed by consistently smaller rates of recovery as storage time progressed. In contrast, estimated population sizes for Ea153N in the vicinity of wound sites were consistently an order of magnitude higher after 7 days of cold storage compared with samples taken shortly after inoculation (pre-dump tank in Table 4). In pear, incubation of fruit at room temperature for 30 days after storage resulted in detection of Ea153N on 2 of 16 fruit in 2005 (average of 5 CFU per wound site), but no detection of the pathogen on similarly treated fruit in 2006.

\section{DISCUSSION}

Experiments and surveys performed in this study provided data useful toward understanding the potential for co-occurrence of E. amylovora with mature, winter pear fruit produced in the

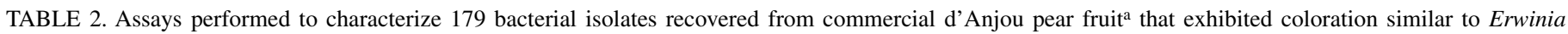
amylovora grown on filter membranes on the surface of Miller Schroth medium

\begin{tabular}{|c|c|c|c|c|c|}
\hline $\begin{array}{l}\text { Valley location of } \\
\text { sampled orchards }\end{array}$ & Sample date & Disease in orchard(s) & Number of fruit ${ }^{\mathrm{b}}$ & $\begin{array}{l}\text { Number of positive } \\
\text { Ea153N controls }\end{array}$ & $\begin{array}{l}\text { Number of fruit } \\
\text { with E. amylovora }\end{array}$ \\
\hline \multicolumn{6}{|l|}{2003} \\
\hline Hood River, OR & $9 / 08$ & No & 300 & $6 / 6$ & 0 \\
\hline Yakima, WA & $9 / 10$ & No & 300 & $6 / 6$ & 0 \\
\hline Rogue, OR & $9 / 15$ & No & 100 & $2 / 2$ & 0 \\
\hline Wenatchee, WA & $9 / 17$ & No & 300 & $6 / 6$ & 0 \\
\hline \multicolumn{6}{|l|}{2004} \\
\hline Hood River, OR & $8 / 31$ & Yes & 100 & $2 / 2$ & 0 \\
\hline Hood River, OR & $8 / 31$ & No & 400 & $8 / 8$ & 0 \\
\hline Wenatchee, WA & $8 / 30$ & Yes & 500 & $8 / 8$ & 0 \\
\hline Wenatchee, WA & $8 / 30$ & No & 200 & $4 / 4$ & 0 \\
\hline Rogue, OR & $9 / 01$ & Yes & 100 & $2 / 2$ & 0 \\
\hline Rogue, OR & $9 / 01$ & No & 100 & $2 / 2$ & 0 \\
\hline Yakima, WA & $9 / 06$ & No & 400 & $8 / 8$ & 0 \\
\hline Okanogan, WA & $9 / 06$ & No & 300 & $6 / 6$ & 0 \\
\hline \multicolumn{6}{|l|}{2005} \\
\hline Yakima, WA & $9 / 05$ & No & 300 & $6 / 6$ & 0 \\
\hline Yakima, WA & $9 / 05$ & No & 300 & $6 / 6$ & 0 \\
\hline Wenatchee, WA & $9 / 07$ & Yes & 500 & $10 / 10$ & 1 \\
\hline Wenatchee, WA & $9 / 07$ & No & 300 & $6 / 6$ & 0 \\
\hline Rogue, OR & $9 / 09$ & Yes & 100 & $2 / 2$ & 0 \\
\hline Rogue, OR & $9 / 09$ & No & 100 & $2 / 2$ & 0 \\
\hline Hood River, OR & $9 / 12$ & Yes & 200 & $4 / 4$ & 0 \\
\hline Hood River, OR & $9 / 12$ & No & 100 & $2 / 2$ & 0 \\
\hline Okanogan, WA & $9 / 13$ & No & 300 & $6 / 6$ & 0 \\
\hline Hood River, OR & $9 / 19$ & Yes & 100 & $2 / 2$ & 0 \\
\hline Hood River, OR & $9 / 19$ & No & 200 & $4 / 4$ & 0 \\
\hline
\end{tabular}

${ }^{a}$ The wash from each fruit was passed through a $0.2 \mu \mathrm{m}$ filter followed by incubation of the filter on Miller Schroth medium for 3 to 7 days.

${ }^{b}$ In each orchard, four pear fruit were sampled from each of 25 haphazardly located trees for a total of 100 fruit per orchard.

${ }^{c}$ Number of positive detections of Ea153N followed by number of control samples processed.

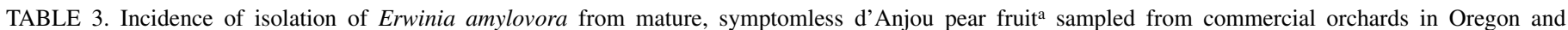
Washington in 2003, 2004, and 2005

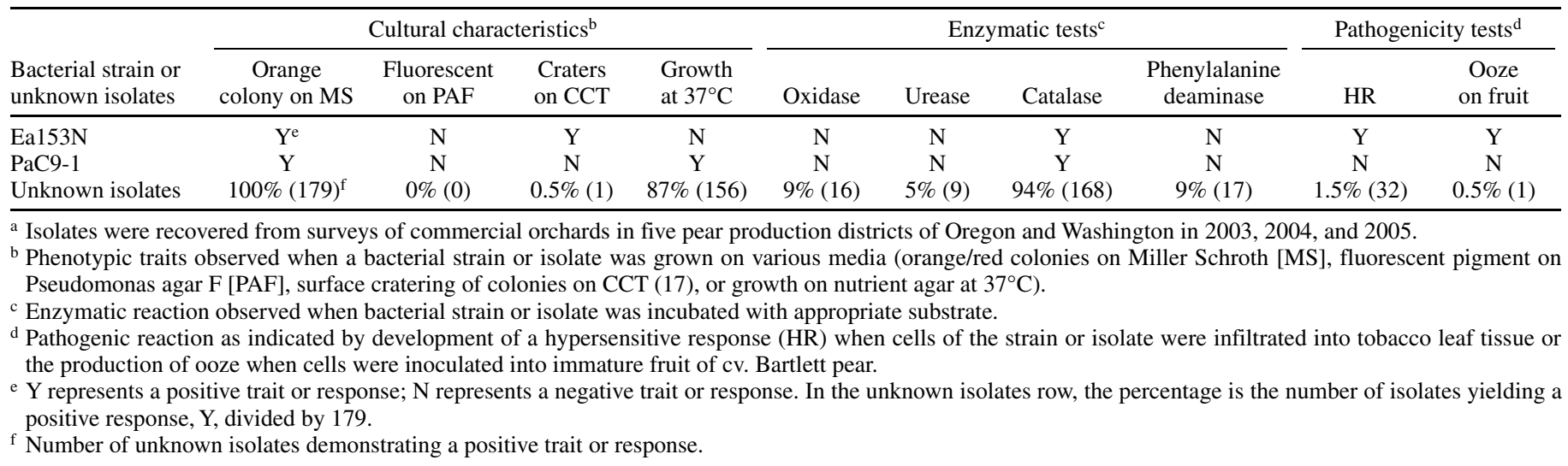


Pacific Northwest region of the United States. For countries that do not have fire blight, co-occurrence of the pathogen with the fruit is essential to the hypothesized disease introduction pathway on which phytosanitary restrictions to fruit importation are grounded. For apple, similar experiments, risk analyses, and regulatory proceedings have concluded that the likelihood of successful establishment of E. amylovora in a new geographic area via importation of commercial fruit is negligible $(29,41,42)$. For this study, the use of established bacterial recovery methods and the inclusion of apple fruit as a control provide a link to previous efforts, which, we believe, can lead to a sharper analysis and discussion of the potential association of E. amylovora with healthy pear fruit, and the phytosanitary regulations pertaining to the export and import of this commodity.

The first experiments characterized the survival of E. amylovora on pear fruit surfaces in orchard environments and provided a baseline from which to judge the epiphytic potential of the
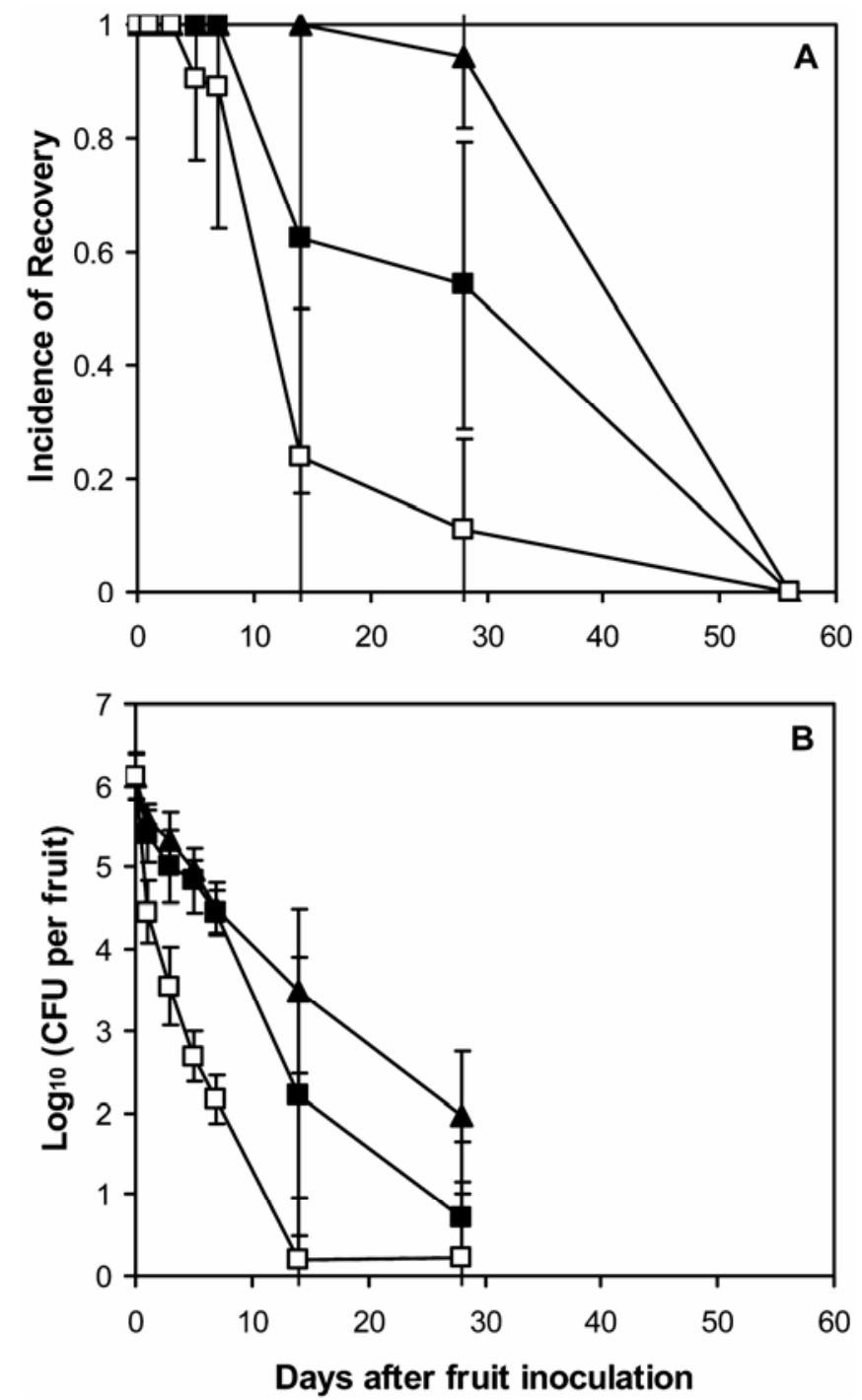

Fig. 3. A, Incidence of recovery and $\mathbf{B}$, mean size of detectable populations (expressed as $\log _{10}[\mathrm{CFU}$ per fruit]) of Erwinia amylovora strain Ea153N on surfaces of 'd'Anjou' pear as influenced by postharvest storage condition. In the laboratory, mature fruit were inoculated to runoff with Ea153N $(1 \times$ $10^{7} \mathrm{CFU} / \mathrm{ml}$ ) and divided among three storage environments: ambient ( $\square$, $\left.20^{\circ} \mathrm{C}\right)$, and two refrigerated environments $\left(0^{\circ} \mathrm{C}, 86\right.$ to $90 \%$ relative humidity) with regular $\left(\boldsymbol{\square}, 21 \% \mathrm{O}_{2}, 0.1 \% \mathrm{CO}_{2}\right)$ or controlled $\left(\boldsymbol{\Delta}, 1.5 \% \mathrm{O}_{2}, 1 \% \mathrm{CO}_{2}\right)$ atmospheres. For each sample time, 10 fruit per storage treatment were sampled, washed individually, and dilution plated and/or filter assayed onto Miller Schroth medium. Data from two independent experiments are combined in the figure. Vertical bars drawn through each point represent \pm one standard deviation of the mean. pathogen and its expected longevity when dispersed from diseased tissues onto healthy fruit. We mimicked natural dissemination by utilizing ooze of $E$. amylovora from diseased tissues and resuspended, freeze-dried cells of the pathogen as inocula, both of which have been reported to be comprised of cells that show superior survival in the environment relative to cells harvested fresh from artificial media $(31,33)$. After deposition, the results depicted an organism in a survival phase, typified by declining incidence of detection and population size, as opposed to a growth phase, such as that observed when cells are inoculated onto floral stigmata $(33,37)$. For both pear and apple, at 2 weeks after inoculation, the detectable population size of the pathogen declined by $>99.99 \%$, and after this point, the detection of the pathogen on fruit occurred infrequently (Fig. 1). Subsamples of fruit tissues revealed that surviving cells were associated with the calyx, and that the pathogen was not detected on the stem or skin. As Rosen (31) and Roberts et al. (29) speculated for cells in ooze, the poor survival of E. amylovora on plant surfaces may be due to fluctuating temperatures and relative humidity in the orchard environment. For a regional perspective, this first experiment also highlighted the climatic conditions typical for pear production. The region is semi-arid, and pear trees are rarely wet after the first of July. For example, for this study, rainfall averaged 23 (Corvallis), 6 (Medford), and $4 \mathrm{~mm}$ (Wenatchee) per month over the three summers, with June the wettest and July the driest month. Consequently, unlike fruit production areas in the eastern United States where the summer shoot blight phase of the disease occurs with regularity (13), fire blight in the Pacific Northwest is mostly a disease of the spring season, when active cankers coincide with significant rain events.

The calyx survival studies provided evidence that floral populations of E. amylovora can persist on pear and apple fruit for a period of time after bloom, but that persistence is characterized by small numbers of cells detected on fewer and fewer fruit as the summer progresses. Recovery of populations of E. amylovora occurred infrequently at harvest (12 of 360 sampled pear fruit with an average of 7 CFU per fruit), and in both 2005 and 2006, the pathogen was not detected on fruit at the end of a 7-week cold storage period. In contrast, populations of the nonpathogenic bacterial epiphyte $P$. agglomerans persisted in relatively high populations $\left(\approx 1 \times 10^{4} \mathrm{CFU}\right.$ per calyx $)$ on most fruit through the summer and into the period of cold storage, indicating that this organism is better adapted to epiphytic survival than is the fire blight pathogen. Roberts et al. (30) also isolated P. agglomerans (syn. Erwinia herbicola) in high frequency from mature apple fruit sampled from commercial orchards in Washington State, and noted that persistence of this bacterium on fruit after harvest was not influenced by time in storage. As we reported in a previous study (33), fluorescent microspheres were a useful control in this experiment because they could be observed on the calyxes of 73 to $95 \%$ of fruit from which we attempted to isolate E. amylovora, indicating that a similar proportion of the flowers received an initial dose of the pathogen, and that lack of detection of the pathogen at harvest and during storage was not due to the flowers escaping the initial inoculations. For the Bosc pear and Gala apple inoculations in 2005, and for both pear inoculations in 2006, the inoculation with Ea153N $\left(1 \times 10^{5} \mathrm{CFU}\right.$ per $\left.\mathrm{ml}\right)$ resulted in high incidences of blossom blight (70 to $85 \%$ of blossom clusters became diseased), demonstrating the virulence of this strain. On healthy fruit, patterns of survival for Ea153N and the avirulent strain Ea153 $\mathrm{HrpL}^{-}$were similar, suggesting that the ability to survive epiphytically was not strongly associated with the ability to cause disease. Based on data from both seasons, there were no apparent differences in the patterns of calyx end survival on pear compared with those observed on apple. Like the conclusions made in regard to calyx-end survival on apple $(16,29,30,36)$, there is a low probability that a floral, epiphytic population of E. amylovora can persist on calyxes of symptomless pear fruit through 
the summer, but the size of the surviving populations is small, and from our data, unable to persist through a postharvest cold period.

The commercial orchard surveys were made in each of the major pear production areas of the Pacific Northwest, and within each area, we attempted to represent the orchard-to-orchard spectrum of fire blight incidence that occurred within a specific season. The disease was not observed in orchards labeled apparently without fire blight, whereas in orchards described as with fire blight, the incidence of disease ranged from a few blighted shoots in the entire orchard to several blighted branches per tree. Because the isolation or detection of E. amylovora from commercial fruit was rare (1 of 5,600 fruit), the hypothesis that the presence of fire blight in an orchard increases the likelihood of detection of the pathogen from fruit was not supported. Logically, disease in the orchard should increase this likelihood $(13,16,39)$, and the one fruit from which we detected $32 \mathrm{CFU}$ of the pathogen was from an orchard with blighted shoots on most trees. Notably, other bacteria were detected on nearly all samples $(>99 \%)$, suggesting, at least for the production areas surveyed, that the relative epiphytic fitness of E. amylovora on fruit surfaces is of greater significance in understanding phytosanitary risk than is proximity to potential sources of inoculum. The conclusion derived from the results of this survey is essentially identical to a similar survey of apple fruit grown in the same region (30): nonpathogenic bacterial epiphytes can be isolated from the surfaces of most, if not all, commercially produced pear fruit sampled in the orchard at harvest, but the detection of epiphytic populations of the fire blight pathogen on these fruit is an exceptionally infrequent event.

The question as to whether E. amylovora can reside as a quiescent endophyte within mature symptomless apple fruit has been addressed in several studies $(2,30,39,41,42)$. Its importance stems from observations that endophytic cells of E. amylovora produced in diseased shoots and released into the vascular system can be a source of inoculum for infection of rootstocks and propagation materials $(15,22,25,37)$. Fruit, however, are thought to be protected from cells moving in the vascular system because of the abscission zone formed between the branch spur and fruit pedicel $(14,42)$. Our field trials, designed to measure the potential for endophytic infestations of mature, symptomless pear fruit, represented a moderate disease event, with the development and extension of two large cankers on the fruit-bearing branches of each of the experimental d'Anjou pear trees. Size of the expanding cankers was somewhat greater in Wenatchee, WA, compared with Medford, OR, and in Wenatchee, one fruit was found to harbor a small epiphytic population of the pathogen. E. amylovora was not detected inside of fruit at either location as measured by nested PCR or by incubation of core and cortex tissue in selective enrichment broth, even in fruit as close as $5 \mathrm{~cm}$ to the proximal edge of an expanding canker. Similar to our results, Roberts et al. (30) was unable to detect E. amylovora in core and cortex tissue of 1,555 mature symptomless fruit harvested from apple trees with oozing fire blight cankers. The panel of judges in a recent World Trade Organization trade dispute resolution hearing stated "there is not sufficient scientific evidence to conclude that mature symptomless apples would harbor endophytic populations of bacteria" $(41,42)$, with Roberts et al. $(29,30)$ and expert testimony cited as the primary sources of evidence. In contrast, Azegami et al. (2, reviewed in literature citation 42), in greenhouse studies, reported movement of E. amylovora into nearly mature apple fruit after artificial insertion of at least $1 \times 10^{5} \mathrm{CFU}$ of the pathogen into spur tissue 17 to 30 days before harvest. To our knowledge, the detection of

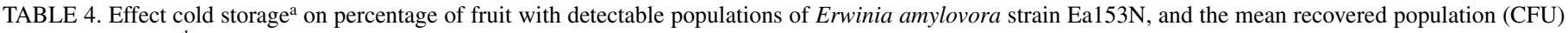
after small wounds ${ }^{\mathrm{b}}$ were created near inoculation sites on mature, symptomless pear and apple fruit near harvest

\begin{tabular}{|c|c|c|c|c|c|c|c|c|c|c|}
\hline \multirow[b]{2}{*}{$\operatorname{Host}^{\mathrm{c}}$} & \multirow[b]{2}{*}{ Year } & \multirow{2}{*}{$\begin{array}{l}\text { Inoculum } \\
\text { dose }\end{array}$} & \multirow{2}{*}{$\begin{array}{l}\text { Dump tank } \\
\text { disinfestant }^{\mathrm{d}}\end{array}$} & \multirow{2}{*}{$\begin{array}{l}\text { Pre-dump } \\
\text { tank }\end{array}$} & \multirow{2}{*}{$\begin{array}{l}\text { Post-dump } \\
\text { tank }\end{array}$} & \multicolumn{4}{|c|}{ Days in cold storage } & \multirow{2}{*}{$\begin{array}{l}\text { Post-cold } \\
\text { storage }^{\mathrm{e}}\end{array}$} \\
\hline & & & & & & 7 & 14 & 28 & 49 & \\
\hline \multirow[t]{2}{*}{ Pear } & 2004 & $1 \times 10^{3}$ & SOPP & $100 \% \mathrm{f}$ & $53 \%$ & $27 \%$ & $27 \%$ & $0 \%$ & $0 \%$ & n.d.g \\
\hline & & & & $96 \pm 15$ & $43 \pm 43$ & $50 \pm 59$ & $80 \pm 78$ & & & \\
\hline \multirow[t]{3}{*}{ Pear } & 2005 & $1 \times 10^{3}$ & SOPP & $\begin{array}{l}20 \% \\
3 \pm 6\end{array}$ & $0 \%$ & $0 \%$ & $0 \%$ & $0 \%$ & $0 \%$ & $0 \%$ \\
\hline & & $1 \times 10^{4}$ & SOPP & $67 \%$ & $23 \%$ & $43 \%$ & $47 \%$ & $57 \%$ & $13 \%$ & $13 \%$ \\
\hline & & & & $43 \pm 31$ & $10 \pm 12$ & $220 \pm 143$ & $204 \pm 136$ & $261 \pm 145$ & $90 \pm 133$ & $5 \pm 1$ \\
\hline \multirow[t]{6}{*}{ Pear } & 2006 & $1 \times 10^{3}$ & SOPP & $34 \%$ & $10 \%$ & $10 \%$ & $7 \%$ & $0 \%$ & $0 \%$ & $0 \%$ \\
\hline & & & & $5 \pm 7$ & $29 \pm 18$ & $3 \pm 4$ & $239 \pm 237$ & & & \\
\hline & & $1 \times 10^{4}$ & SOPP & $90 \%$ & $47 \%$ & $67 \%$ & $47 \%$ & $54 \%$ & $37 \%$ & $0 \%$ \\
\hline & & & & $137 \pm 85$ & $163 \pm 165$ & $1,376 \pm 1,848$ & $793 \pm 859$ & $263 \pm 303$ & $222 \pm 294$ & \\
\hline & & $1 \times 10^{4}$ & $\mathrm{NaOCl}$ & $64 \%$ & $30 \%$ & $67 \%$ & 47 & $54 \%$ & $27 \%$ & $0 \%$ \\
\hline & & & & $40 \pm 53$ & $101 \pm 128$ & $272 \pm 351$ & $317 \pm 291$ & $428 \pm 555$ & $230 \pm 261$ & \\
\hline \multirow[t]{2}{*}{ Apple } & 2004 & $1 \times 10^{3}$ & SOPP & $100 \%$ & $13 \%$ & $20 \%$ & $0 \%$ & $0 \%$ & $0 \%$ & n.d. \\
\hline & & & & $88 \pm 4$ & $1 \pm 0$ & $11 \pm 6$ & & & & \\
\hline \multirow[t]{4}{*}{ Apple } & 2005 & $1 \times 10^{3}$ & SOPP & $13 \%$ & $0 \%$ & $0 \%$ & $0 \%$ & $0 \%$ & $0 \%$ & $0 \%$ \\
\hline & & & & $4 \pm 5$ & & & & & & \\
\hline & & $1 \times 10^{4}$ & $\mathrm{NaOCl}$ & $50 \%$ & $7 \%$ & $3 \%$ & $3 \%$ & $0 \%$ & $0 \%$ & $0 \%$ \\
\hline & & & & $70 \pm 103$ & $96 \pm 1$ & $115 \pm 0$ & $86 \pm 0$ & & & \\
\hline \multirow[t]{6}{*}{ Apple } & 2006 & $1 \times 10^{3}$ & $\mathrm{NaOCl}$ & $47 \%$ & $27 \%$ & $20 \%$ & $0 \%$ & $0 \%$ & $0 \%$ & $0 \%$ \\
\hline & & & & $6 \pm 4$ & $7 \pm 4$ & $29 \pm 26$ & & & & \\
\hline & & $1 \times 10^{4}$ & $\mathrm{NaOCl}$ & $87 \%$ & $27 \%$ & $53 \%$ & $13 \%$ & $13 \%$ & $0 \%$ & $0 \%$ \\
\hline & & & & $18 \pm 6$ & $5 \pm 6$ & $153 \pm 133$ & $83 \pm 21$ & $13 \pm 14$ & & \\
\hline & & $1 \times 10^{4}$ & SOPP & $73 \%$ & $20 \%$ & $53 \%$ & $27 \%$ & $20 \%$ & $0 \%$ & $0 \%$ \\
\hline & & & & $18 \pm 6$ & $2 \pm 2$ & $232 \pm 40$ & $68 \pm 10$ & $31 \pm 26$ & & \\
\hline
\end{tabular}

\footnotetext{
a Storage temperatures averaged 2 and $0^{\circ} \mathrm{C}$ in Corvallis and Wenatchee, respectively.

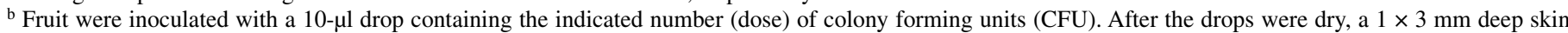
puncture was introduced at the site of inoculation with a sterile nail.

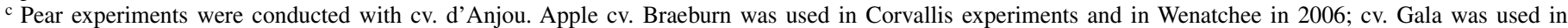
Wenatchee in 2005.

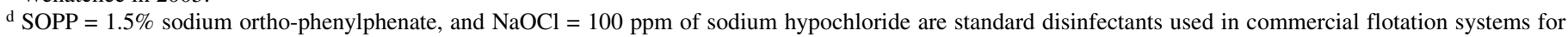
pear and apple, respectively. After inoculation, fruit were incubated at room temperature ( 20 to $\left.22^{\circ} \mathrm{C}\right)$ for $24 \mathrm{~h}$ prior to dump tank immersion.

e After cold storage, fruit were incubated at room temperature $\left(20\right.$ to $\left.22^{\circ} \mathrm{C}\right)$ for an additional 30 days before assay.

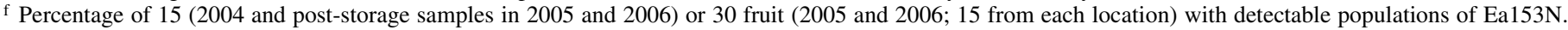
Mean population size (CFU per fruit) and standard deviation are computed only for fruit on which Ea153N was detected.

g Not determined
} 
endophytic populations of E. amylovora in mature, symptomless winter pear has not been demonstrated previously; fire blight lesions on the external surface of nearly mature fruit of summer pear cv. Bartlett, however, has been reported from Washington State $(10,44)$.

Postharvest survival of E. amylovora on pear fruit was evaluated in two experiments, both with protocols that utilized concentrations of inoculum that were at least several orders of magnitude greater than observed on mature fruit harvested during the orchard studies. The first postharvest experiment was similar to the initial orchard experiment and was designed to evaluate potential for epiphytic survival of the pathogen on nonwounded fruit stored under different environmental conditions. As reported by Ceroni et al. (8), cold temperatures $\left(0^{\circ} \mathrm{C}\right)$ prolonged pathogen survival relative to warm temperatures $\left(20\right.$ to $\left.22^{\circ}\right)$, and similarly, a cold, controlled atmosphere $\left(1.5 \% \mathrm{O}_{2}, 1 \% \mathrm{CO}_{2}\right)$ prolonged storage relative to a cold, regular atmosphere $\left(21 \% \mathrm{O}_{2}, 0.1 \% \mathrm{CO}_{2}\right)$. Nonetheless, as in the field, incidence of detection and population size declined with time, with no detection of the pathogen after 56 days, regardless of the storage environment. The observed rate of decline of population size of E. amylovora on pear fruit in cold storage (an order of magnitude every 6 to 8 days) was very similar to the rates of decline reported by Taylor and Hale (35), who measured postharvest survival of the fire blight pathogen on calyxes of stored apple. The second experiment, although realistic in its emulation of industrial fruit handling practices, also represented an improbable scenario in that a small wound (mimicking a stem puncture or other small abrasion caused during handling) was placed on fruit at a position that coincided with a concentration of pathogen cells confined within an area that represented approximately one thousandth of the total fruit surface. Our goal was to understand, in a dose response framework, how the reportedly greater susceptibility of pear fruit relative to apple would influence pathogen persistence in storage when intimately associated with wounded host cells. The results confirmed our expectation that wounded pear fruit provided a somewhat more conducive environment for persistence of E. amylovora compared with that of wounded apple fruit, but this result was dosedependent, with the difference between the hosts only apparent at the highest concentration of pathogen inoculum (i.e., $1 \times 10^{4} \mathrm{CFU}$ in close proximity to the wound site). For both pear and apple, the data also showed small but consistent increases in pathogen population size over the first 7 to 14 days of cold storage followed by declining incidence of detection and population size in the latter portion of the storage period. These increases in recovered population size during the early part of the storage period, however, were considerably smaller than that reported for growth of E. amylovora in a nutrient broth incubated at $2{ }^{\circ} \mathrm{C}$ for 20 days (35). Macroscopically, both pear and apple fruit remained symptomless at the wound sites, although a very small, necrotic discoloration was apparent at the base of the wound of some fruit that were split with a knife. Pear fruit that received the high dose of Ea153N $\left(1 \times 10^{4} \mathrm{CFU}\right.$ in the vicinity of the wound site $)$ also were used to monitor the ability of the pathogen to grow on fruit after the 49-day cold storage period. Pears incubated at room temperature for 30 days post-cold storage showed a low incidence of detection with an estimated population size two orders of magnitude smaller (i.e., $5 \mathrm{CFU}$ per fruit) than observed on fruit sampled at the end of the cold storage period (Table 4).

Collectively, the results of this study can be compared with a published risk model developed to assess the probability that the pathway to successful establishment of E. amylovora in a diseasefree area can be completed by importation of commercial apple fruit (29). In that model, independent probabilities (P) were assigned to steps of the pathway: $\mathrm{P}_{1}$, the fruit is infested with E. amylovora; $\mathrm{P}_{2}$, E. amylovora survives storage; $\mathrm{P}_{3}$, contaminated fruit is discarded near host; $\mathrm{P}_{4}$, host is receptive; and $\mathrm{P}_{5}$, E. amylovora is transferred to the new host and infection occurs.
Using these probabilities and an estimate of the potential number of fruit exported annually to the new area, Roberts et al. (29) found the likelihood of successful introduction of fire blight to a new area ranged from once every 11,000 to 38,000 years, depending on levels of phytosanitary precaution taken prior to export. In this likelihood estimate, their derived values for $\mathrm{P}_{1}$, depending on phytosanitary scenario, ranged from 0.001 (one in a thousand fruit) to 0.035 ( 1 in 30 fruit), which are considerably higher than the 1 in 5,600 fruit that we obtained in our survey of commercial orchards. Similarly, $\mathrm{P}_{2}$ was estimated to be 0.1 ( 1 in 10 fruit), which also was greater than we observed in the epiphytic and calyx survival experiments. We assume that the published values of $\mathrm{P}_{3}$ and $\mathrm{P}_{4}$ for pear would be the same as those estimated for apple, although in absolute terms, the potential number of pear fruit exported would be considerably less than apple (fresh pear production in the Pacific Northwest is one eighth that of apple). $\mathrm{P}_{5}$, the probability that E. amylovora is transferred to a new host and infection occurs is largely dependent on how well this pathogen could increase its population size on mature discarded fruit to enable its transfer to a receptive host, most likely by visiting insects $(29,37)$. We found that epiphytic survival of $E$. amylovora through a postharvest chilling period is expected to be an exceptionally rare event given the unrealistically high population size required for persistence. Moreover, after storage (and required fruit chilling), our data also indicated that mature pear fruit were an unsuitable substrate for continued reproduction of this pathogen. We conclude that the potential for successful establishment of E. amylovora into disease-free environments via the importation of fresh winter pear fruit is no greater than that predicted for apple; with both crops, the risk is extremely low.

\section{ACKNOWLEDGMENTS}

Research support was provided by the Northwest Horticultural Council, the Technical Assistance for Specialty Crops program of the USDA Foreign Agricultural Service, Fresh Pear Committee, Washington Tree Fruit Research Commission, Oregon State University Agricultural Experiment Station, and the USDA-Agricultural Research Service. Avirulent E. amylovora strain Ea153 $\mathrm{HrpL}^{-}$was field released under USDA APHIS permit 03-279-01r. We thank M. Willett and R. Roberts for critical suggestions to the manuscript.

\section{LITERATURE CITED}

1. Anonymous. 2004. EPPO standards: Diagnostic protocols for regulated pests, PM7/20 Erwinia amylovora. EPPO Bull. 34:159-171.

2. Azegami, K., Tsukamoto, T., Matsuura, T., Inoue, Y., Uematsu, H., Ohara, T., Mizuno, A., Yoshida, K., Bessho, H., Sato, S., Kimura, S., and Goto, M. 2006. Erwinia amylovora can pass through the abscission layer of fruit-bearing twigs and invade apple fruit during fruit maturation. J. Gen. Plant Pathol. 72:43-45.

3. Bereswill, S., Bugert, P., Bruchmuller, I., and Geider, K. 1995. Identification of the fire blight pathogen, Erwinia amylovora by PCR assays with chromosomal DNA. Appl. Environ. Microbiol. 61:2636-2642.

4. Bereswill, S., Pahl, A., Bellemann, P., Wolfgang, Z., and Geider, K. 1992. Sensitive and species-specific detection of Erwinia amylovora by polymerase chain reaction analysis. Appl. Environ. Microbiol. 58:35223526.

5. Billing, E., Crosse, J. E., and Garrett, C. M. E. 1960. Laboratory diagnosis of fire blight and bacterial blossom blight of pear. Plant Pathol. 9:19-25.

6. Bonn, G. W., and van der Zwet, T. 2000. Distribution and economic importance of fire blight. Pages 37-54 in: Fire Blight: The Disease and Its Causative Agent, Erwinia amylovora. J. L. Vanneste, ed. CAB International, London.

7. Calzolari, A., Peddes, A., Mazzuchi, U., Mori, P., and Garzena, L. 1982. Occurrence of Erwinia amylovora in buds of asymptomatic apple plants in commerce. J. Phytopathol. 103:156-162.

8. Ceroni, P., Minardi, P., Babini, V., Traversa, F., and Mazzucchi, U. 2004. Survival of Erwinia amylovora on pears and on fruit containers in cold storage and outdoors. EPPO Bull. 34:109-115.

9. Chen, P. M., Richardson, D. G., and Mellenthin, W. M. 1982. Differences in biochemical composition between 'Beurre d'Anjou' and 'Bosc' pears 
during fruit development and storage. J. Am. Soc. Hortic. Sci. 107:807812.

10. Covey, R. P. 1975. Symptom expression of Bartlett pear fruit to Erwinia amylovora in relation to fruit maturity and harvest. Plant Dis. Rep. 59:266-267.

11. Crosse, J. E., and Goodman, R. N. 1973. A selective medium for and a definitive colony characteristic of Erwinia amylovora. Phytopathology 63:1425-1426.

12. Dueck, J. 1974. Survival of Erwinia amylovora in association with mature apple fruit. Can. J. Plant Sci. 54:349-351.

13. Dueck, J., and Morand, J. B. 1975. Seasonal changes in the epiphytic population of Erwinia amylovora on apple and pear. Can. J. Plant Sci. 50:1007-1012.

14. Gonzalez-Carrions, Z. H., Lozoya-Gloria, E., and Roberts, J. A. 1998. Recent developments in abscission: Shedding light on the shedding process. Trends Plant Sci. 3:10-14

15. Gowda, S. S., and Goodman, R. N. 1970. Movement and persistence of Erwinia amylovora in shoot, stem and root of apple. Plant Dis. Rep. 54:576-580.

16. Hale, C. N., McRae, E. M., and Thomson, S. V. 1987. Occurrence of Erwinia amylovora on apple fruit in New Zealand. Acta Hortic. 217:33-40.

17. Ishimaru, C. A., and Klos, E. J. 1984. New medium for detecting Erwinia amylovora and its use in epidemiological studies. Phytopathology 74:1342-1345

18. Ishimaru, C. A., Klos, E. J., and Brubaker, R. R. 1988. Multiple antibiotic production by Erwinia herbicola. Phytopathology 78:746-750.

19. Johnson, K. B., Stockwell, V. O., Burgett, D. M., Sugar, D., and Loper, J. E. 1993. Dispersal of Erwinia amylovora and Pseudomonas fluorescens by honey bees to apple and pear blossoms. Phytopathology 83:478-484

20. Johnson, K. B., Stockwell, V. O., and Sugar, D. 2000. Assessment of environmental factors influencing growth and spread of Pantoea agglomerans on and among blossoms of apple and pear. Phytopathology 90:1285-1294.

21. Keil, H. L., and van der Zwet, T. 1972. Recovery of Erwinia amylovora from symptomless stems and shoots of Jonathon apple and Bartlett pear trees. Phytopathology 62:39-42.

22. Lewis, S., and Goodman, R. N. 1965. Mode of penetration and movement of the fire blight bacterium in apple leaf and stem tissue. Phytopathology 55:719-723.

23. MacManus, P. S., and Jones, A. L. 1995. Detection of Erwinia amylovora by nested PCR and PCR dot blot and reverse blot hybridizations. Phytopathology 85:618-623.

24. Miller, T. D., and Schroth, M. N. 1972. Monitoring the epiphytic population of Erwinia amylovora on pear with a selective medium. Phytopathology 62:1175-1182.

25. Momol, M. T., Norelli, J. L., Piccioni, D. E., Momol, E. A., Gustafson, H. L., Cummins, J. N., and Aldwinckle, H. S. 1998. Internal movement of Erwinia amylovora through symptomless apple scion tissues into the rootstock. Plant Dis. 82:646-650.

26. Paulin, J.-P. 2000. Erwinia amylovora: General characteristics, biochemistry and serology. Pages $87-115$ in: Fire Blight: The Disease and Its Causative Agent, Erwinia amylovora. J. L. Vanneste, ed. CAB International, London.
27. Pusey, P. L. 1997. Crab apple blossoms as a model for research on biological control of fire blight. Phytopathology 87:1096-1102.

28. Pusey, P. L., and Curry, E. A. 2004. Temperature and pomaceous flower age related to colonization by Erwinia amylovora and antagonists. Phytopathology 94:901-911.

29. Roberts, R. G., Hale, C. N., van der Zwet, T., Miller, C. E., and Redlin, S. C. 1998. The potential for spread of Erwinia amylovora and fire blight via commercial apple fruit; a critical review and risk assessment. Crop Prot. 17:19-27.

30. Roberts, R. G., Reymond, S. T., and McLaughlin, R. J. 1989. Evaluation of mature apple fruit from Washington State for the presence of Erwinia amylovora. Plant Dis. 73:917-921.

31. Rosen, H. R. 1938. Life span and morphology of the fire blight bacteria as influenced by relative humidity, temperature and nutrition. J. Agric. Res. 56:239-258.

32. Stockwell, V. O., Johnson, K. B., and Loper, J. E. 1996. Compatibility of bacterial antagonists of Erwinia amylovora with antibiotics used for fire blight control. Phytopathology 86:834-840.

33. Stockwell, V. O., Johnson, K. B., and Loper, J. E. 1998. Establishment of bacterial antagonists of Erwinia amylovora on pear and apple blossoms as influenced by inoculum preparation. Phytopathology 88:506-513.

34. Stockwell, V. O., McLaughlin, R. J., Henkels, M. D., Loper, J. E., Sugar, D., and Roberts, R. G. 1999. Epiphytic colonization of pear stigmas and hypanthia by bacteria during primary bloom. Phytopathology 89:11621168.

35. Taylor, R. K., and Hale, C. N. 2003. Cold storage affects survival and growth of Erwinia amylovora on the calyx of apple. Lett. Appl. Microbiol. 37:340-343.

36. Taylor, R. K., Hale, C. N., Gunson, F. A., and Marshall, J. W. 2003. Survival of the fire blight pathogen, Erwinia amylovora, in calyxes of apple fruit discarded in an orchard. Crop Prot. 22:603-608.

37. Thomson, S. V. 2000. Epidemiology of fire blight. Pages 9-36 in: Fire Blight: The Disease and Its Causative Agent, Erwinia amylovora. J. L. Vanneste, ed. CAB International, London.

38. Traversa, F., and Mazzucchi, U. 2002. One year survival of Erwinia amylovora in symptomless pear scions. J. Plant Pathol. 84:157-160.

39. van der Zwet, T., Thomson, S. V., Covey, R. P., and Bonn, W. G. 1990. Population of Erwinia amylovora on external and internal apple fruit tissues. Plant Dis. 74:711-716.

40. Wei, Z.-M., and Beer, S. V. 1995. HrpL activates Erwinia amylovora hrp gene transcription and is a member of the ECF subfamily of $\sigma$-factors. $J$ Bacteriol. 177:6201-6210.

41. World Trade Organization. 2003. Japan - Measures Affecting the Importation of Apples. Dispute Settlement 245, Report of the Panel, WT/DS245/R, July.

42. World Trade Organization. 2005. Japan - Measures Affecting the Importation of Apples. Dispute Settlement 245, Recourse to Article 21.5 of the DSU by the United States, WT/DS245/RW, June.

43. World Trade Organization. 2005. Japan - Measures Affecting the Importation of Apples. Dispute Settlement 245, Notification of mutually agreed solution, WT/DS245/21, September.

44. Wright, T. R. 1947. Fire blight of Bartlett pears in storage. Plant Dis. Rep. 32:58-61. 